W dniach 26-29 maja 2009 r. w Pradze odbyła się 15 konferencja poświęcona profesjonalnym elektronicznym zasobom informacji - INFORUM 2009¹. Głównym inicjatorem tego spotkania była, jak co roku, firma Albertina icome Praha, która dostarcza na rynek czeski i słowacki produkty do zarządzania elektronicznymi zasobami informacji oraz organizacji konsorcjów. Od tego roku do organizatorów dołączył także Uniwersytet Ekonomiczny w Pradze. Celem sympozjum było przedstawienie najnowszych kierunków rozwoju w dziedzinie elektronicznych zasobów informacji. Mimo że uczestnikami konferencji w przeważającej większości byli Czesi i Słowacy, nie zabrakło też bibliotekarzy z innych krajów, głównie z centralnej, wschodniej i południowej Europy.

W ramach tegorocznego INFORUM przygotowano trzy typy spotkań:

- warsztaty - prowadzone przez zaproszonych gości, tj. Davida Bawdena z Wielkiej Brytanii i Herberta van de Sompela ze Stanów Zjednoczonych,

- dwie równolegle odbywające się sesje konferencyjne - prezentujące na przemian referaty naukowo-zawodowe oraz wystąpienia sponsorów,

${ }^{1}$ Oficjalna strona konferencji: INFORUM 2009 - 15th conference on Professional Information Resources [on-line] [dostęp 30 listopada 2009]. Dostępny w World Wide Web: http:// www.inforum.cz/archiv/inforum2009/en/.

\section{INFORUM 2009 - 15 Konferencja na temat Profesjonalnych Zasobów Informacyjnych (Praga, 26-29 maja 2009 r.)}

- sesję plakatową - stanowiącą uzupełnienie wystąpień konferencyjnych i będącą okazją do zaprezentowania czeskich i zagranicznych rozwiązań w zakresie szeroko rozumianych technologii informacyjnych.

Ze względu na to, że sposób organizacji sympozjum nie pozwalał na jednoczesne uczestnictwo we wszystkich zaproponowanych spotkaniach, w niniejszym tekście zostaną zaprezentowane najciekawsze $\mathrm{z}$ polskiego i naukowego punktu widzenia inicjatywy i wystąpienia, których autorki (jako jedyne przedstawicielki Polski) miały okazję wysłuchać. Wydaje się to o tyle uzasadnione, że pełen przegląd wszystkich pokazów multimedialnych, tekstów referatów i plakatów zaprezentowanych podczas konferencji zamieszczony został na jej stronie internetowej.

W pierwszej grupie spotkań na szczególną uwagę - zdaniem autorek - zasłużył trzygodzinny warsztat pod nazwą "Information generations: change or continuity?” (pol. „Pokolenia informacyjne: zmiana czy kontynuacja?"), prowadzony przez D. Bawdena - profesora City University w Londynie. Był on poświęcony wyodrębnie- 
niu i charakterystyce grup współczesnych użytkowników bibliotek. Według amerykańsko-angielskiej klasyfikacji dzielą się oni (w zależności od daty urodzin) na: Veterans (urodzeni w latach 30.), Baby Boomers (urodzeni w latach 50.), Generation X (urodzeni w latach 70.), Generation Y (urodzeni pod koniec lat 80.) oraz Google Generation (urodzeni po 2000 r.). Bliższe poznanie cech i potrzeb każdej z tych grup pozwala bibliotekarzom lepiej konstruować zasoby i serwisy oferowane w bibliotekach. Warsztat podzielony był na cztery części, tj. wprowadzenie do tematu, dyskusję, burzę mózgów oraz pracę $\mathrm{w}$ grupach. Uczestnicy z Czech, Polski, Słowacji i Serbii mieli okazję wymienić doświadczenia z pracy w swoich bibliotekach.

W sesji inaugurującej konferencję D. Bawden, jako zaproszony gość honorowy, wygłosił także referat. Jego futurologiczne wystąpienie pod tytułem "Library/Information prospects: three views of the future” (pol. „Perspektywy dla biblioteki/informacji: trzy wizje przyszłości") przedstawiało trzy hipotezy na temat rozwoju bibliotek i informacji naukowej. Pierwsza - to niewielkie zmiany, bazujące na wyrobionej, dobrej marce bibliotek jako miejsc, gdzie można znaleźć potrzebną informację. Druga - to możliwość zmiany nazwy $\mathrm{z}$ „biblioteka” na „centrum informacyjne" lub „centrum odkrywania informacji", połączenie serwisów bibliotecznych z informatycznymi, integracja bibliotek z instytucjami kultury czy biznesu. Trzecia - biblioteka jako serwis, nie jako fizyczne miejsce, jej zasoby dostęp- ne zdalnie zewsząd, bibliotekarze jako specjaliści informacji, doradcy, edukatorzy, ale także naukowcy i wydawcy.

Kolejny interesujący referat wprowadzający przedstawił H. van de Sompel z Los Alamos National Laboratory (Stany Zjednoczone). Zaprezentował on refleksje odnoszące się do projektów zrealizowanych w ostatniej dekadzie, a mających na celu zmianę komunikacji naukowej (m.in. SFX, OpenURL, OAI-PMH, MESUR). Relację ze swoich wieloletnich badań zaprezentowała również Amerykanka Carol Tenopir. Obserwacje statystyk dotyczących wykorzystania dokumentów i ankiety przeprowadzane wśród użytkowników stanowiły dla niej podstawę wyodrębnienia grup czytelników i określenia wartości pewnych typów źródeł dla tych grup.

Później obrady toczyły się w ośmiu następujących sesjach:

1) "Matching content with user intent” (pol. „Dostosowanie zawartości do potrzeb użytkownika"),

2) "Electronic resources in the digital age” (pol. „Zasoby elektroniczne w erze cyfrowej"),

3) "Trends and updates in using information” (pol. „Trendy i innowacje w wykorzystaniu informacji"),

4) "Practical aspects of using electronic resources in companies knowledge management” (pol. „Praktyczne aspekty wykorzystania zasobów elektronicznych w firmach. Zarządzanie wiedzą"),

5) "Inside out publishing - Open Access” (pol. „Publikowanie od podszewki - Open Access"), 
6) "Evaluation and electronic information resources” (pol. „Ocena a elektroniczne zasoby informacji"),

7) "Using and administration of electronic information resources" (pol. „Wykorzystanie i administrowanie elektronicznymi zasobami informacji"),

8) "Access to electronic information resources and their usage in e-learning” (pol. „Dostęp do elektronicznych zasobów informacji i ich wykorzystanie w e-learningu").

W sesji pierwszej na uwagę zasługiwały dwa wystapienia. Marydee Ojala, redaktorka amerykańskiego czasopisma „ONLINE”, w prezentacji “See it, hear it: multimedia search goes beyong text” (pol. „Zobacz to, usłysz to: wyszukiwanie multimediów wykracza poza tekst") przedstawiła internetowe narzędzia do wyszukiwania nietekstowych zasobów internetowych są to na przykład: SearchMe.com, SearchVideo.com, SomePoint.com czy Kartoo. Zuzana Helinsky ze Szwecji w referacie "Encourage users into the library” (pol. „Zachęcanie użytkowników do korzystania z biblioteki") przekonywała, że aby zachęcić użytkowników do odwiedzania bibliotek, trzeba dobrze poznać i zrozumieć ich potrzeby, co wymaga czasu i wielu ryzykownych przedsięwzięć, ale nie należy bać się błędów i niepowodzeń.

W części poświęconej zasobom elektronicznym w dobie cyfrowej ("Electronic resources in the digital age") wystąpił Dominik Fellner z Czech, który zaprezentował referat "Digital portfolio as a professional development tool" (pol. „Cyfrowe portfolio narzędziem rozwo- ju zawodowego"). Autor przekonywał w nim, że w dzisiejszych, „cyfrowych” czasach posiadanie portfolio (pewnego rodzaju $\mathrm{CV}$, uzupełnionego odnośnikami, zdjęciami i filmami) umieszczonego w Internecie jest bardzo przydatne i może pomóc w nawiązywaniu zarówno prywatnych, jak i zawodowych kontaktów. Prelegent przedstawił także ogólnodostępne sieciowe narzędzia, których można użyć, aby takie portfolio stworzyć, oraz zaprezentował portale internetowe służące nawiązywaniu kontaktów zawodowych.

W sesji “Practical aspects of using electronic resources in companies knowledge management" ponownie zainteresowanie wzbudziła M. Ojala. W wystąpieniu pt. "Using social media for competitive intelligence” (pol. „Wykorzystanie mediów społecznościowych w wywiadzie gospodarczym") zaprezentowała ona zalety i wady wykorzystywania informacji z różnych serwisów Web $2.0 \mathrm{w}$ wywiadzie gospodarczym. Referentka wykazała także przydatność tego typu narzędzi do monitorowania wizerunku własnej firmy bądź instytucji (ang. reputation monitoring). W tej samej sesji interesujący referat wygłosił również Martin Mrazek - "The concept of knowlegde centered company” (pol. „Koncepcja firmy opartej na wiedzy"), w którym opisał wprowadzony w firmie Semanta system zarządzania wiedzą, działający na podstawie wiedzy wspartej szkoleniami dla pracowników.

W części zatytułowanej “Using and administration of electronic information resources" szczególne zaintereso- 
wanie wzbudziły dwa referaty - Lenki Nĕmečkovej z Biblioteki Praskiego Uniwersytetu Technologicznego oraz Vladimira Karena, przedstawiciela firmy Albertina icome Praha. W pierwszym wystąpieniu pt. "Web 2.0 tools to support research and development in engineering” (pol. „Narzędzia Web 2.0 jako wsparcie prac badawczych i rozwoju w naukach technicznych") autorka podkreślała, jak ważne jest zastosowanie nowoczesnych technologii w bibliotece do wsparcia procesu dydaktycznego i naukowego. Chcąc potwierdzić tę tezę, Nĕmečková omówiła systemy do zarządzania bibliografią, alerty oraz możliwości personalizacji baz danych do własnych potrzeb. Drugi prelegent, $\mathrm{w}$ prezentacji "E-resources in wider context: interaction, integration, customization and personalization" (pol. „Zasoby elektroniczne w szerszym kontekście: interakcja, integracja, kastomizacja i personalizacja"), rozwinął temat nowych technologii i możliwości personalizowania narzędzi wyszukiwawczych. Zwrócił on także uwagę na potrzebę wprowadzenia zmian $\mathrm{w}$ bibliotecznych strukturach i strategiach gromadzenia zbiorów. Jego zdaniem, punkt ciężkości w tym zakresie należy przenieść z gromadzonych dotąd zasobów drukowanych na elektroniczne. Trzeba także zadbać o zbiory elektroniczne i odbudowywać je odpowiednimi narzędziami, jak np. zintegrowanymi systemami do zarządzania zbiorami elektronicznymi, narzędziami do linkowania czasopism (typu SFX czy Serials Solution), aplikacjami do zarządzania bibliografią czy multiwyszukiwarkami.
W sesji "Inside out publishing Open Access” w referacie „Economist online: the new portal for economics" (pol. „Economist online: nowy portal ekonomiczny") Tomáš Pavela z praskiego oddziału Instytutu CERGE-EI (The Center for Economic Research and Graduate Education - Economics Institute) zaprezentował międzynarodowy projekt budowy portalu ekonomicznego, skupiającego monografie, artykuły oraz materiały konferencyjne udostępniane na zasadach wolnego dostępu. W omawianej sesji swoje referaty przedstawiły także autorki niniejszego artykułu. Aneta Ostrowska, w referacie zatytułowanym "Open Access Journals Quality - How to measure It?" (pol. „Jakość czasopism Open Access jak ją mierzyć?"), scharakteryzowała podstawowe wskaźniki biblio- i webometryczne oraz użytkowe, których zestawienie może stanowić o jakości danego czasopisma. Zuzanna Wiorogórska z kolei - w prelekcji “Open Access: how to benefit from it reasonably and how to make the own contribution in its development?” (pol. „Open Access: jak rozsądnie z niego korzystać i jak mieć własny wkład w jego rozwój?”) - dokonała przeglądu najciekawszych i najbardziej przydatnych z punktu widzenia bibliotekarzy polskich i zagranicznych inicjatyw Open Access.

Jak wcześniej zasygnalizowano, poza referatami naukowo-zawodowymi, swoje prezentacje podczas sesji konferencyjnych mieli także sponsorzy - przedstawiciele firm dobrze znanych w środowisku bibliotekarskim na całym świecie (m.in. ProQuest, Elsevier, 
Wolters Kluwer, Bowker czy ExLibris). Mimo że niektóre z pokazów miały czysto reklamowy charakter, można było odnotować także kilka takich, które zasłużyły na uwagę ze względu na ciekawy sposób demonstracji komercyjnego produktu jako rozwiązania konkretnego problemu bibliotecznego. W czasach, kiedy standardem dla każdej biblioteki jest posiadanie dostępu do co najmniej kilku elektronicznych baz danych, użytkownikom należy zapewnić jak największy komfort korzystania $\mathrm{z}$ nich. Pomocą w tym zakresie służą narzędzia optymalizacji użytkowania źródeł elektronicznych. Kilka z nich zostało zaprezentowanych również w ramach INFORUM 2009. Firma ProQuest przedstawiła Serials Solutions 360 narzędzie całościowo zarządzające kolekcją czasopism elektronicznych, które dzięki wielu przydatnym funkcjom, jak statystyki wykorzystania, raporty porównawcze czy możliwości importowania i eksportowania danych, pozwala na efektywne zarządzanie bardzo dużym zbiorem e-czasopism. Kolejną ofertę zaprezentowała firma Bowker. Jej produkt - Aqua Browser - to najnowszej klasy multiwyszukiwarka, wzorowana na systemach wyszukiwawczych oferowanych przez komercyjne wyszukiwarki typu Google, przeznaczona do poszukiwań naukowych w obrębie zasobów oferowanych przez daną bibliotekę. Podstawową różnicą między Aqua Browser a innymi dostępnymi obecnie produktami tego typu jest maksymalna personalizacja procesu wyszukiwawczego. W podobnym stylu zaprezentowała się także firma ExLibris, w Pol- sce znana głównie jako producent zintegrowanego systemu bibliotecznego Aleph. Z bogatej oferty najnowszych produktów informatycznych przedstawiciele spółki omówili Verde - zintegrowany system zarządzania zasobami elektronicznymi (można by go nazwać Alephem XXI wieku), oraz MetaLib - multiwyszukiwarkę pozwalającą na scalenie wszystkich typów zasobów bibliotecznych i przeszukiwanie ich podczas realizacji jednej kwerendy informacyjnej.

Podsumowując konferencję INFORUM 2009, warto jeszcze zwrócić uwagę na jej poziom organizacyjny. Na uznanie w tym kontekście zasługują m.in. zapewnienie symultanicznego przekładu treści wszystkich prelekcji na język angielski, profesjonalne opracowanie materiałów konferencyjnych i ich szybka publikacja w Internecie. Rozwiązaniem godnym do naśladowania przez organizatorów innych sesji naukowych jest także rozsyłanie do uczestników konferencji ankiety ewaluacyjnej, pozwalającej nie tylko na ocenę poziomu i organizacji sympozjum, ale także na składanie propozycji tematów, które mogłyby być poruszane podczas kolejnych tego typu spotkań.

\section{Aneta Ostrowska \\ uczestniczka studiów doktoranckich z zakresu bibliologii, prowadzonych na Wydziale Nauk Historycznych Uniwer- sytetu Mikołaja Kopernika w Toruniu}

\section{Zuzanna Wiorogórska}

Biblioteka Uniwersytecka $w$ Warszawie, doktorantka Laboratoire GERiiCO Uniwersytetu Lille 3 (Francja) 